\title{
Replacement of Maize by Wheat Bran on Carcass and Sensory Characteristics of Pigs
}

\author{
N. Elanchezhian ${ }^{*}$ and K. Ally ${ }^{2}$ \\ ${ }^{1}$ Department of Animal Nutrition, Rajiv Gandhi Institute of Veterinary Education and \\ Research, Puducherry- 605 009, India \\ ${ }^{2}$ Department of Animal Nutrition, College of Veterinary and Animal Sciences, Mannuthy, \\ Thrissur, Kerala, India-680651 \\ *Corresponding author
}

\section{A B S T R A C T}

\section{Keywords}

Maize, Wheat bran,

Pig, Carcass,

Sensory quality

Article Info

Accepted:

23 April 2020

Available Online:

10 May 2020
The experiment was conducted to assess the effect of replacement of maize by different levels of wheat bran on carcass characteristics and sensory qualities of pigs. Thirty weaned Large White Yorkshire piglets were randomly divided into three groups and randomly allotted to the three dietary treatments, T1 (control ration as per NRC, 1998), T2 (50 per cent of maize of control ration replaced by wheat bran) and T3 (100 per cent of maize of control ration replaced by wheat bran. Except dressing percentage all the other parameters were not different from each other for all three treatments. The dressing percentage was higher $(\mathrm{P}<0.01)$ in $\mathrm{T} 1$ than that of $\mathrm{T} 3$. Even though there was no significant difference between treatments, the flavor and overall acceptability was better in T3 group. The partial (50 per cent) replacement of the maize in the feed for pigs by wheat bran did not affect the carcass and sensory characteristics, whereas complete (100 per cent) replacement resulted in poor dressing percentage, water holding capacity and drip loss. Hence it can be concluded that maize can be replaced by wheat bran at 50 per cent level without adverse effect.

\section{Introduction}

Cereal grain forms the major source of energy in the swine feed. Even though, India produces more than 20 million MT of maize per year, it could meet only 60 per cent of the requirement in the country. The lower availability and increasing price of maize, necessitates an alternative energy source for incorporation in the swine feed. Wheat bran is a byproduct of wheat processing industry and can be included as a source of energy in swine ration. However, studies on the effects of adding wheat bran to swine diets have yielded variable results.

Bhar et al., (2000) reported that maize can be completely replaced by wheat bran without 
any adverse effect on their feed intake, body weight and carcass characteristics. Brouns et al., (1995) also used wheat bran at 67 per cent without any bad effect. Kyriazakis and Emmans (1995) found decreased feed intake when fibrous feed materials like wheat bran added at higher levels.

But study on carcass and sensory characteristics of pigs by feeding of wheat bran are scanty. Hence the present experiment was undertaken to assess the effect of replacement of maize by different levels of wheat bran on carcass and sensory characteristics of pigs.

\section{Materials and Methods}

The experiment was conducted to assess the effect of replacement of maize by different levels of wheat bran on carcass and sensory characteristics in pigs. Thirty weaned female Large White Yorkshire piglets were randomly divided into three groups with five replicates in each group. All piglets were housed in the same shed and were maintained under identical management conditions throughout the experimental period of 70 days.

Restricted feeding was followed by allowing them to consume as much as they could, within a period of one hour and the balance feed was collected and weighed after each feeding. Clean drinking water was provided ad libitum in all the pens throughout the experimental period. Daily feed intake was recorded.

The animals were fed with standard grower ration containing 18 per cent of $\mathrm{CP}$ and 3265 $\mathrm{kcal}$ of $\mathrm{ME} / \mathrm{kg}$ of feed up to $50 \mathrm{~kg}$ body weight and finisher ration with 16 per cent $\mathrm{CP}$ and $3265 \mathrm{kcal}$ of $\mathrm{ME} / \mathrm{kg}$ of feed from $50 \mathrm{~kg}$ body weight as per NRC (1998). The three groups of piglets were randomly allotted to the three dietary treatments, T1 (control ration as per NRC, 1998), T2 (50 per cent of maize of control ration replaced by wheat bran) and T3 (100 per cent of maize of control ration replaced by wheat bran). Ingredient composition of pig grower and finisher ration were given in the Table 1 . The ration used in this study had similar nutrients as per NRC (1998; 2012) recommendations.

\section{Slaughter experiments}

Five animals from each treatment were slaughtered at the end of the experiment to study various carcass parameters, weight of internal organs, physico-chemical parameters and sensory evaluation of meat. Data on carcass weight, carcass length (anterior edge of $1^{\text {st }}$ rib to anterior edge of pelvic bone), back fat thickness (between 10-11 ${ }^{\text {th }}$ ribs), loin eye area (between $10-11^{\text {th }}$ ribs) and weight of the internal organs such as liver, kidney, heart, spleen, diaphragm, stomach and intestine were recorded. Dressing percentage and weight of internal organs as percentage of body weight were calculated. Marbling of meat was judged based on USDA (1985) grade chart. The $\mathrm{pH}(\mu \mathrm{pH}$ system-Systronics, India), Water holding capacity (WHC) (Wardlaw et al., (1973), Colour (Hunterlab Miniscan XE plus SpectrophotometerVirginia, USA) and drip loss (Lawrie, 1998) of the meat were estimated. Taste panel assessment of the longissimus muscle of pigs fed three experimental rations was done with ten semi trained panelists using Nine point Hedonic scale score card.

\section{Statistical analysis}

Data collected on various parameters were statistically analyzed by Completely Randomized Design (CRD) method and means were compared by Duncan Multiple Range Test (DMRT) using Statistical Package for Social Studies (SPSS. 17.0.1v, 2008) software. 


\section{Results and Discussion}

\section{Carcass characteristics}

Data on carcass weight, dressing percentage, carcass length, loin eye area, back fat thickness, marbling and weight of internal organs of the pigs maintained on the three dietary treatments are shown in Table 2 . The dressing percentage of pigs was $74.94,73.93$ and 72.59 , carcass length was $30.20,30.26$ and 29.78 inch, loin eye area was $31.14,31.10$ and $27.81 \mathrm{~cm}^{2}$, back fat thickness was 2.32 , 2.44 and $2.12 \mathrm{~cm}$ in $\mathrm{T} 1, \mathrm{~T} 2$ and $\mathrm{T} 3$ group, respectively. The marbling observed was moderate for all the groups of pigs. Except dressing percentage all the other parameters were not different from each other for all three treatments. The statistical analysis of data shows that the dressing percentage was higher $(\mathrm{P}<0.01)$ in $\mathrm{T} 1$ than that of $\mathrm{T} 3$, whereas $\mathrm{T} 1$ and $\mathrm{T} 2, \mathrm{~T} 2$ and $\mathrm{T} 3$ are similar.

Bhar et al., (2000) observed no significant difference in carcass traits of crossbred pigs fed diet with 0,50 and 100 per cent replacement of maize by wheat bran. Significantly lower dressing percentage observed in T3 treatment might have been due to higher crude fibre level (9.40 per cent) in the diet because wheat bran was included at 64.90 per cent when 74 per cent of maize was replaced (100 per cent replacement). This is in agreement with the observation of Pond et al., (1988) who reported reduced carcass weight, carcass length, backfat thickness and longissimus muscle area in pigs fed high crude fibre diets. In T3 group, stomach and intestine recorded higher weight (13.02 per cent of live weight) than other group, might have contributed for lower dressing percentage. This is in agreement with Ewan (2000) who opined that feed rich in crude fibre contributes relatively more weights of digestive tract to slaughter weight, reducing the dressing percentage.
There was no difference $(\mathrm{P}<0.05)$ between treatment for any weight of internal organs, whereas Pond et al., (loc. cit) observed increased relative weight of the liver, heart, stomach, small intestine, cecum, and colon in pigs fed high crude fibre diets.

\section{Physico-chemical parameters and sensory evaluation}

Physico-chemical parameters and sensory evaluation of meat of pigs maintained on the three experimental rations $\mathrm{T} 1, \mathrm{~T} 2$ and $\mathrm{T} 3$ are presented in Table 3. The $\mathrm{pH}$ of meat recorded within two hours of slaughter was $5.63,5.82$ and 5.55 , respectively for the three dietary treatments and the values were statistically similar. The water holding capacity ranged from 14.0 to 26.80 per cent was lower $(\mathrm{P}<0.01)$ in $\mathrm{T} 1$ compared to $\mathrm{T} 2$ and T3. Feeding of diet with 14 per cent animal fat to pigs resulted in accumulation of fat in the muscle, which could probably observe more water. The drip loss was higher in T3 than that of T1group (11.17 Vs 7.25\%) probably because of higher water content of muscle of pigs fed high fat (14 per cent animal fat) diet. The colour of the meat in the three groups on an average was 63.39 to 66.58 for lightness (1), 6.72 to 10.27 for redness (a) and 14.12 to 15.59 for yellowness (b) and the values were statistically similar. The observation made in the present study agrees with the findings of Gatlin et al., (2002) and Dugan et al., (2004). Bee et al., (2002) stated that carcass characteristics were significantly differed by energy concentration but not by dietary sources.

Sensory evaluation of meat of pigs was 5.90 to 6.30 for colour, 5.50 to 6.10 for flavor, 4.90 to 5.20 for juiciness, 5.20 to 5.70 for tenderness and 5.40, 5.90 and 6.40 for overall acceptability in the Nine point Hedonic scale score card and values were statistically similar. 
Table.1 Ingredient composition of pig grower and finisher rations, \%

\begin{tabular}{|c|c|c|c|c|c|c|}
\hline \multirow[t]{2}{*}{ Ingredients } & \multicolumn{3}{|c|}{ Grower rations ${ }^{1}$} & \multicolumn{3}{|c|}{ Finisher rations ${ }^{1}$} \\
\hline & $\mathrm{T} 1$ & $\mathrm{~T} 2$ & T3 & $\mathrm{T} 1$ & $\mathrm{~T} 2$ & T3 \\
\hline Yellow maize & 70 & 35 & 0 & 74 & 37 & $\mathbf{0}$ \\
\hline Wheat bran & 1.5 & 31 & 59.8 & 3.6 & 34.7 & 64.9 \\
\hline Soyabean meal & 26.25 & 25.5 & 25.0 & 20.5 & 19.7 & 19.2 \\
\hline Animal fat & 0 & 6.5 & 13 & $\mathbf{0}$ & 7 & 14 \\
\hline Salt & 0.5 & 0.5 & 0.5 & 0.5 & 0.5 & 0.5 \\
\hline Dicalcium phosphate & 0.9 & 0.4 & 0 & 0.65 & 0.10 & $\mathbf{0}$ \\
\hline Calcite & 0.85 & 1.1 & 1.7 & 0.75 & 1.0 & 1.4 \\
\hline Total & 100 & 100 & 100 & 100 & 100 & 100 \\
\hline Nicomix $A B_{2} D_{3} K^{1}, g$ & 25 & 25 & 25 & 25 & 25 & 25 \\
\hline Nicomix $\mathrm{BE}^{2}, \mathrm{~g}$ & 25 & 25 & 25 & 25 & 25 & 25 \\
\hline Zinc Oxide ${ }^{3}, \mathrm{~g}$ & 45 & 13 & 0 & 30 & 0 & 0 \\
\hline Oxylock antioxidant $^{4}, \mathrm{~g}$ & 10 & 10 & 10 & 10 & 10 & 10 \\
\hline
\end{tabular}

${ }^{1}$ Nicomix A, $B_{2}, D_{3}, K$ (Nicholas Piramal India Ltd, Mumbai) containing Vitamin A- 82,500 IU, Vitamin $B_{2}-50$ $\mathrm{mg}$, Vitamin $\mathrm{D}_{3}-12,000 \mathrm{IU}$ and Vitamin K-10 mg per gram.

${ }^{2}$ Nicomix BE (Nicholas Piramal India Ltd, Mumbai) containing Vitamin $\mathrm{B}_{1}-4 \mathrm{mg}$, Vitamin $\mathrm{B}_{6}-8 \mathrm{mg}$, Vitamin $\mathrm{B}_{12}-40 \mathrm{mg}$, Niacin-60 mg, Calcium pantothenate- $40 \mathrm{mg}$ and Vitamin E-40 mg per gram.

${ }^{3}$ Zinc oxide (Nice Chemicals Pvt. Ltd., Kochi) containing $81.38 \%$ of Zn.

${ }^{4}$ Oxylock antioxidant (Vetline Ltd., Indore) contains Ethoxyquin, Butylated HydroxyToluene (BHT), Chelators and Surfactantant.

Table.2 Carcass characteristics and weight of internal organs as percentage of live weight of pigs maintained on the three experimental rations

\begin{tabular}{|c|c|c|c|}
\hline Parameters & \multicolumn{3}{|c|}{ Treatments } \\
\cline { 2 - 4 } & T1 & T2 & T3 \\
\hline Live weight, $\mathrm{kg}$ & $74.70 \pm 2.80$ & $75.80 \pm 2.44$ & $68.90 \pm 1.81$ \\
\hline Carcass weight, $\mathrm{kg}$ & $55.98 \pm 2.15$ & $56.07 \pm 2.08$ & $50.03 \pm 1.46$ \\
\hline ** Dressing percentage & $74.94 \pm 0.79^{\mathrm{b}}$ & $73.93 \pm 0.49^{\mathrm{ab}}$ & $72.59 \pm 0.49^{\mathrm{a}}$ \\
\hline Carcass length, inch & $30.20 \pm 0.11$ & $30.26 \pm 0.35$ & $29.78 \pm 0.42$ \\
\hline Loin eye area, $\mathrm{cm}^{2}$ & $31.14 \pm 1.90$ & $31.10 \pm 1.70$ & $27.81 \pm 0.96$ \\
\hline Back fat thickness, cm & $2.32 \pm 0.31$ & $2.44 \pm 0.15$ & $2.12 \pm 0.18$ \\
\hline Marbling & Moderate & moderate & Moderate \\
\hline Heart, \% & $0.32 \pm 0.02$ & $0.30 \pm 0.01$ & $0.31 \pm 0.02$ \\
\hline Lungs, \% & $1.23 \pm 0.06$ & $1.19 \pm 0.05$ & $1.13 \pm 0.09$ \\
\hline Liver, \% & $1.94 \pm 0.07$ & $1.81 \pm 0.07$ & $1.80 \pm 0.07$ \\
\hline Kidneys, \% & $0.46 \pm 0.07$ & $0.39 \pm 0.05$ & $0.39 \pm 0.02$ \\
\hline Spleen, \% & $0.22 \pm 0.01$ & $0.18 \pm 0.01$ & $0.20 \pm 0.02$ \\
\hline Diaphragm, \% & $0.42 \pm 0.02$ & $0.45 \pm 0.04$ & $0.47 \pm 0.03$ \\
\hline Stomach and intestine, \% & $11.28 \pm 0.67$ & $11.60 \pm 0.58$ & $13.02 \pm 0.50$ \\
\hline
\end{tabular}

${ }^{1}$ Mean of 5 observations of slaughtered animals with SE

a, b - Means with different superscripts within the same row differ significantly **Significant $(\mathrm{P}<0.01)$ 
Table.3 Physico-chemical parameters and sensory evaluation of meat of pigs maintained on the three experimental rations

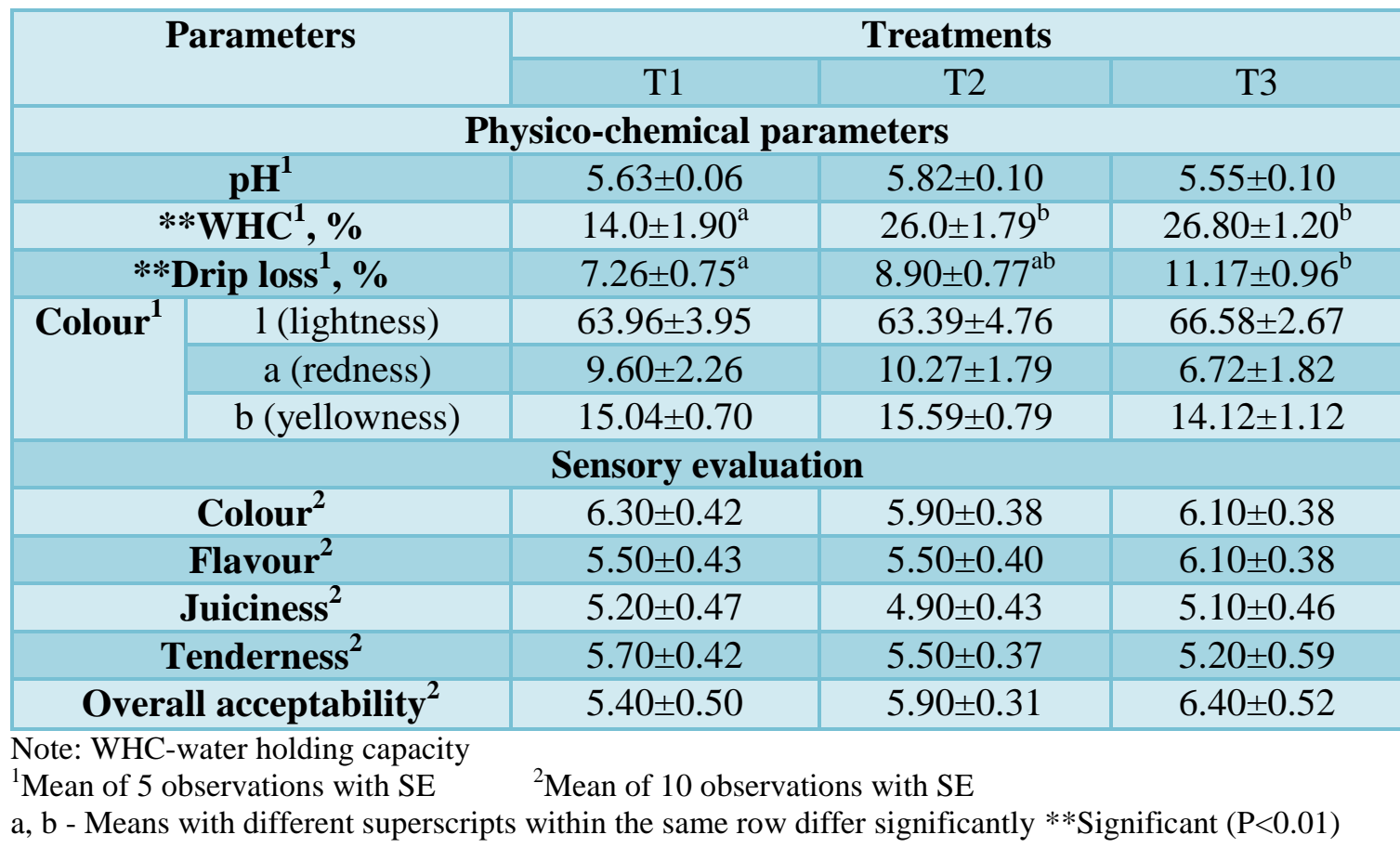

Even though there was no significant difference between treatments, the flavor and overall acceptability was better in high fat group. Lack of significant effect on colour by level of fat in the diet was also reported by Gatlin et al., (loc. cit), Dugan et al., (loc. cit), Apple et al., (loc. cit) and Browne et al., (2011).

An evaluation of the results obtained in this study indicates that partial (50 per cent) replacement of the maize in the feed for pigs by wheat bran did not affect the carcass and sensory characteristics. Full (100 per cent) replacement of maize in the feed by wheat bran resulted in poor dressing percentage, water holding capacity and drip loss.

\section{Acknowledgment}

The authors are very much thankful to Dean, College of Veterinary and Animal Sciences, Mannuthy for providing necessary facilities for successful conduct of the work.

\section{References}

Apple, J. K., Maxwell, C.V., Sawyer, J.T., Kutz, B.R., Rakes, L.K., Davis, M.E., Johnson, Z.B., Carr, S.N. and Armstrong, T.A. 2007. Interactive effect of ractopamine and dietary fat source on quality characteristics of fresh pork bellies. J. Anim. Sci. 85: 26822690.

Bee, G., Gebert, S. and Messikommer, R. 2002. Effect of dietary energy supply and fat source on the fatty acid pattern of adipose and lean tissues and lipogenesis in the pig. J. Anim. Sci. 80(6): 1564-1574.

Bhar, R., Pathak, N.N. and Paul, S. 2000. Performance of crossbred (Landrace $\mathrm{X}$ local Indian) finisher barrows fed maize or wheat bran based diets: Short note. Asian-Aust. J. Anim. Sci. 13(10): 1429-1432.

Brouns, F., Edwards, S.S. and English, P.R. 1995. Influence of fibrous feed 
ingredients on voluntary intake of dry sows. Anim. Feed Sci. Technol. 54: 301-313.

Browne, N.A., Apple, J.K. and Yancey, J.W.S. 2011. Phase-feeding dietary fat to growing-finishing pigs fed dried distillers grains with soluble III. Quality characteristics of bacon. AAES Research series 597, Alabama Agriculture experiment Station, Auburn, Alabama, USA, pp. 83-85.

Dugan, M.E.R., Aalhus, J.L., Robertson, W.M., Rolland, D.C. and Larsen, I.L. 2004. Practical dietary levels of canola oil and tallow have differing effects on gilt and barrow performance and carcass composition. Can. J. Anim. Sci. 84(4): 661-671.

Ewan, R.C. 2000. Energy utilization in swine nutrition. In: Lewis, A.J. and Southern, L.L. (eds.), Swine Nutrition $\left(2^{\text {nd }}\right.$ Ed.). CRC press, Florida, USA, pp. 85-94.

Gatlin, L.A., See, M.T., Hansen, J.A., Sutton, D. and Odle, J. 2002. The effects of dietary fat sources, levels, and feeding intervals on pork fatty acid composition. J. Anim. Sci. 80: 16061615 .

Kyriazakis, I and Emmans, G.C. 1995. The voluntary feed intake of pigs given feeds based on wheat bran, dried citrus pulp and grass meal, in relation to measurements of feed bulk. Br. J. Nutr. 73: 191-207.

Lawrie, R.A. 1998. Meat Science. (6 ${ }^{\text {th }}$ Ed.). Woodhead Publishing Ltd., England, 336p.

Liao, C.W. and Venum, T.L. 1994. Effects of dietary energy intake by gilts and heat stress from days 3 to 24 or 30 after mating on embryo survival and nitrogen and energy balance. J. Anim. Sci. 72: 2369-2377.

NRC [National Research Council]. 1998. Nutrient Requirements of Swine $\left(10^{\text {th }}\right.$ Ed.).

National Academy of Sciences, Washington, D. C., 210p.

NRC [National Research Council]. 2012. Nutrient Requirements of Swine $\left(11^{\text {th }}\right.$ rev. Ed.). National Academy of Sciences, Washington, D. C., 400p.

USDA [United States Department of Agriculture]. 1985. United States Standards for Grades of Pork Carcasses, U.S. Department of Agriculture, Washington, DC.

Wardlaw, F.B., McCaskill, L.H. and Acton, J.C. 1973. Effect of postmortem muscle changes on poultry meat loaf properties. J. Food Sci. 38: 421-423.

\section{How to cite this article:}

Elanchezhian, N. and Ally, K. 2020. Replacement of Maize by Wheat Bran on Carcass and Sensory Characteristics of Pigs. Int.J.Curr.Microbiol.App.Sci. 9(05): 2925-2930. doi: https://doi.org/10.20546/ijcmas.2020.905.346 